удК 342.9

DOI https://doi.org/10.32837/apdp.v0i87.2798

М. В. Калатур

\title{
ДО ПРОБЛЕМИ ВИЗНАЧЕННЯ ПОНЯТТЯ ІНФОРМАЦІЙНОГО ЗАБЕЗПЕЧЕННЯ ДІЯЛЬНОСТІ СЛІДЧИХ ОРГАНІВ В УКРАЇНІ
}

Постановка проблеми. Як проголошується у Стратегії розвитку інформаційного суспільства в Україні, нині загальносвітовою тенденцією є масштабне, глибинне та динамічне проникнення інформаційно-комунікаційних технологій у всі сфери життєдіяльності особи, суспільства, суб'єктів господарювання та держави [1]. Водночас важливу роль у будь-якій системі управління відіграє система моніторингу й інформаційно-аналітичного забезпечення, що дозволяє відстежувати поточний стан та прогнозувати можливі наслідки. Проте в Україні інформаційно-аналітичне забезпечення розвивається з певним запізненням, унаслідок інерційності змін в органах управління та його уповільненого адаптування до сучасних умов інформаційного світу [2]. Особливе значення інформаційне забезпечення має під час розслідування кримінальних справ в умовах дефіциту відомостей, коли слідчий відчуває брак даних, необхідних йому як для організації розслідування, так і для виявлення слідів злочину, з'ясування механізму злочинної діяльності, встановлення винних у вчиненні злочину тощо. Зокрема, це характерно для слідчих ситуацій, коли не встановлено особу, яка вчинила злочин, а також для розслідування окремих категорій злочинів, як-от терористичні акти, комп'ютерні злочини, злочини, учинені злочинними угрупованнями, іноземцями тощо [3, с. 280]. У зв'язку з наведеним наукова організація праці й інформаційне забезпечення, як одна з їі складових частин, у слідчих підрозділах правоохоронних органів України є пріоритетним напрямом реформування, адже широке застосування інформаційно-комунікаційних технологій та інструментів наукової організації праці $€$ важливою передумовою підвищення ефективності діяльності слідчих органів.

Стан дослідження. Інформаційне забезпечення та наукову організацію праці у правоохоронних органах на різних етапах їхнього становлення та розвитку досліджували І.В. Арістова, В.Г. Афанасьєв, О.М. Бандурка, Ю.М. Батурін, О.В. Бойченко, В.І. Галаган, Р.А. Калюжний, М.В. Колеснікова, С.С. Кудінов, М.М. Мазур, В.М. Плішкін, О.В. Сировой, Р.А. Усманов, В.С. Цимбалюк, М.Я. Швець, Г.М. Шорохова й інші правознавці. Проте внаслідок здійснюваних законодавчих та інституціональних реформ у системі слідчих органів, під впливом технічного прогресу та глобальної інформатизації суспільства інформаційне забезпечення та наукова організація праці у слідчих підрозділах правоохоронних органів України потребують подальшого теоретичного дослідження та вдосконалення.

Мета статті - надати визначення поняття інформаційного забезпечення діяльності слідчих органів в Україні.

Виклад основного матеріалу. Під час дослідження питання інформаційного забезпечення у слідчих підрозділах правоохоронних органів України варто спо- 
чатку звернутися до термінологічного апарату. Так, відповідно до ст. 1 Закону України «Про інформацію» від 2 жовтня 1992 р. № 2657-XII зі змінами та доповненнями, інформація - це будь-які відомості та/або дані, які можуть бути збережені на матеріальних носіях або відображені в електронному вигляді. Під захистом інформації законодавець розуміє сукупність правових, адміністративних, організаційних, технічних та інших заходів, що забезпечують збереження, цілісність інформації та належний порядок доступу до неї [4]. У загальному розумінні інформація - це відомості про що-небудь, наприклад, про якісь предмети, навколишнє середовище тощо. Термін «інформація», як зазначає В.Л. Плескач (лат. informatio означає «пояснення», «викладення», «повідомлення»), спочатку уживався лише щодо засобів зв’язку, а потім у більш широкому розумінні. Автор продовжує, що інформація - це сукупність відомостей про матеріальний і духовний світ, про закономірності й тенденції його розвитку, які можна відтворювати шляхом передачі усним, письмовим або електронним способом [5]. У своєму тлумачному словнику C.I. Ожегов дає таке визначення поняття «інформація»: 1) відомості про навколишній світ і процеси, що протікають у ньому, які сприймаються людиною чи спеціальним пристроєм; 2) повідомлення, які повідомляють про стан речей, про стан будь-чого [6, с. 457]. Згідно з визначеннями, наведеними у словнику іншомовних слів, інформація - це: 1 . Відомості про навколишній світ та процеси, що в ньому протікають, які сприймаються людиною або спеціальним улаштуванням. 2. Повідомлення про стан справ, про стан чого-небудь. Якщо звернутися до філософського тлумачення, то під інформацією розуміють особливий атрибут матерії, пов'язаний з її здатністю до відображення [7, с. 311].

На думку Ю.І. Шемакіна, «інформація» - це семантична сутність матерії, яка має загальну властивість матерії та проявляється в кібернетичних комунікативних процесах. Поняття «матерія» ототожнюється 3 поняттям «система», складовими елементами якої є речовина, енергія, знання. Дані - це відомості, які не можуть виступати інформацією, вони використовуються як будь-який висновок, можливе рішення. А знання - це наслідок пізнавальної діяльності, система понять про дійсність, отриманих з її допомогою [8]. Намагаючись діалектично поєднати всі основні визначення інформації, О.В. Кохановська запропонувала визначити їі як «нематеріальне немайнове благо особливого роду, яке нерозривно пов'язане із життям, з його виникненням і закінченням, яке проявляється як особисте немайнове благо, як результат впливу на людину й інших суб'єктів та об'єкти права, як результат інтелектуальної творчої діяльності і як документовані або публічно оголошені відомості про події та явища, які мали або мають місце в суспільстві, державі та навколишньому середовищі» [8, с. 172].

Необхідно вказати також думку В.С. Цимбалюка, О.М. Гальченка, О.О. Орєхова та В.М. Брижко, які доводять, що з погляду загальносистемного уявлення про сутність поняття, «інформація» має два аспекти: 1) гносеологічний аспект - інформація розглядається як повідомлення, якісне значення його змісту (семантичний аспект значеннєвого змісту інформації). Отже, можна говорити про те, що інформація - це сукупність даних про дійсність, побудована на основі мислення і висновків людей або розв’ язання завдань засобами з «інтелектуальними» можливостями. 
Або інформація - це документальні чи публічні відомості незалежно від форми їх представлення; 2) онтологічний аспект - інформація розглядається як кількісне значення міри пропускної спроможності каналу зв'язку (визначеність і упорядкованість (інтенсивність) потоку повідомлення в мережах передачі даних, що зветься «трафік») й упорядкування повідомлень (організаційний аспект процесу кодування/декодування і передачі/прийому інформаціі). Інформація в даному аспекті розглядається як упорядкована система, яку можна описати математично. Водночас під упорядкованою системою мається на увазі будь-яка алгоритмізована система з об'єктивно заданим алгоритмом, що може бути пізнаний [9, с. 24].

Отже, інформація - це відповідні дані, які використовують уповноважені суб'єкти для здійснення відповідної діяльності. Поняття інформаційного забезпечення ані на законодавчому, ані на доктринальному рівнях не визначено. Так, інформаційне забезпечення являє собою сукупність форм документів, нормативної бази і реалізованих рішень щодо обсягу, розміщення і форм організації інформації, яка циркулює в системі автоматизованого оброблення інформації чи в інформаційній системі [10]. Р.А. Калюжний та В.О. Шамрай трактують поняття інформаційного забезпечення як: діяльність, пов'язану з організацією збору, реєстрації, передачі, зберігання, опрацювання і представлення інформації; забезпеченість системи управління відповідною множиною інформації [11, с. 39]; діяльність суб’єктів управління, яка спрямована на надання службам та підрозділам відомостей, необхідних їм для здійснення покладених на них завдань і функцій, та задоволення відповідних вимог [12, с. 124].

Також під інформаційним забезпеченням розуміють сукупність інформаційних ресурсів, засобів, методів і технологій, які сприяють ефективним комунікаціям у контурі управління й ухваленню оперативних і своєчасних рішень у правоохоронній діяльності [13, с. 168]. Е.Д. Лук'янчиков, у свою чергу, інформаційним забезпеченням називає систему напрямів оптимізації кримінально-процесуальної діяльності у формах дізнання і досудового слідства, які включають постійне узагальнення слідчої практики, виявлення недоліків, проблем, їх наукове розроблення і практичне вирішення [14, с. 339]. Проте, на наш погляд, даний підхід не відображає сутності власне інформаційного забезпечення поряд з іншими видами забезпечення, організації, управління тощо.

Більш детально підходить до даної проблеми В.Л. Синчук, що розглядає інформаційне забезпечення у трьох його аспектах:

1) як компонент дослідницької пізнавальної процедури одержання інформації, відсутньої в адресата;

2) як попередню процедуру одержання необхідної інформації суб'єктом досудового слідства перед провадженням слідчої дії або оцінюванням її результатів, перед ухваленням процесуального рішення почати діяти;

3) як створення умов реалізації принципів інформації: відкритості, доступності, об'єктивності, повноти, точності та вільного обміну; діяльність зі здійснення принципу наочності, що забезпечує єдність сприйняття й абстрактного мислення [15, с. 139]. Проте ми не можемо погодитися з автором, адже вважаємо, що інформаційне забезпечення охоплює не лише «попередню процедуру одержання необхідної інформації», але й усі етапи роботи з нею. 
На відміну від указаних науковців, Є.П. Іщенко слушно зазначає, що змістом інформаційного забезпечення є створення, функціонування та вдосконалення інформаційних систем, які являють собою апаратно-програмні комплекси засобів, що дозволяють здійснювати збір, обробку, накопичення криміналістично значущих даних, їх видачу на запити споживача [16, с. 12].

У свою чергу, М.В. Колеснікова під інформаційним забезпеченням правоохоронних органів розуміє комплексний процес узагальнення практики діяльності правоохоронних органів, що здійснюється за допомогою організаційних, правових, технічних і технологічних заходів, засобів та методів, які забезпечують функціонування системи інформаційних зв'язків між слідчими й іншими учасниками правоохоронної діяльності щодо збирання, оброблення й аналізу інформації $[17$, с. 117]. Із цим ми також не можемо погодитися, адже інформаційне забезпечення може включати не лише «узагальнення практики діяльності», але й обробку якісно нових інформаційних масивів.

Висновки. Отже, підсумовуючи вищевказане, пропонуємо під інформаційним забезпеченням діяльності слідчих органів розуміти складову частину механізму організації слідчої діяльності, що в адміністративно-правовому плані передбачає одержання, збирання, реєстрацію, обробку, передачу, збереження та надання інформації шляхом створення інформаційних ресурсів, баз і систем, автоматизованих робочих місць із використанням новітніх методів і технологій.

\section{Jimepamypa}

1. Про схвалення Стратегії розвитку інформаційного суспільства в Україні : розпорядження Кабінету Міністрів України від 15 травня 2013 р. № 386-р. Верховна Рада України : вебсайт. URL: http://zakon.rada.gov.ua/laws/show/386-2013-\% D1\% 80.

2. Щорічна доповідь про стан інформатизації та розвиток інформаційного суспільства в Україні. Державне агентство з питань електронного урядування України : вебсайт. URL: https://old.e.gov.ua/content/shchorichna-dopovid-pro-rozvytok-informaciynogo-suspilstva.

3. Кудінов С.С. Інформаційне забезпечення розслідування злочинів: сучасний стан та шляхи вдосконалення. Вісник Луганського державного університету внутрішніх справ імені Е.О. Дідоренка. 2011. № 1. С. $280-285$.

4. Про інформацію : Закон України від 2 жовтня 1992 р. № 2657-XII. Відомості Верховної Ради України. 1992. № 48. Ст. 650.

5. Плескач В.Л., Затонацька Т.Г. Інформаційні системи і технології на підприємствах : підручник. Київ : Знання, 2011. 718 с.

6. Ожегов С.И. Словарь русского языка. Москва, 1991. 915 с.

7. Державне управління : навчальний посібник / А.Ф. Мельник та ін. ; за ред. А.Ф. Мельник. Київ : Знання-Прес, 2003. 343 с

8. Шемакин Ю.И. Теоретическая информатика. Москва : МГУ, 1995.

9. Е-будущее и информационное право / В.М. Брыжко и др. Киев : Интеграл, 2002. 264 с.

10. Загальна характеристика інформаційного забезпечення Інформаційні системи і технології в статистииі : навчальний посібник / В.М. Годун, Н.С. Орленко, М.А. Сендзюк ; за ред. В.Ф. Ситника. Київ : КНЕУ, 2003. 267 c. URL: https://library.if.ua/book/80/5658.html.

11. Інформаційне забезпечення управлінської діяльності в умовах інформатизації: організаційно-правові питання теорії і практики : монографія / Р.А. Калюжний та ін. ; за ред. Р.А. Калюжного, В.О. Шамрая. Київ : Акад. ДПС України, 2002. 296 с.

12. Административная деятельность органов внутренних дел. Часть общая : учебник для образовательных учреждений высшего профессионального образования Министерства внутренних дел России / С.Н. Бочаров и др. ; под. ред. А. П. Коренева. Москва : Моск. юрид. ин-т, 1996. 335 с. 
13. Приймак В.М. Прийняття управлінських рішень : навчальний посібник. Кииів : Атіка, 2008. $240 \mathrm{c}$.

14. Лук'янчиков Е.Д. Інформаційне забезпечення розслідування злочинів (правові і тактикокриміналістичні аспекти) : дис. ... докт. юрид. наук: 12.00 .09 . Київ, 2005. 429 с.

15. Синчук В.Л Інформаційне забезпечення досудового слідства : теоретичний аспект. Вісник Академї̈ педагогічних наук України. 2003. № 1 (32). С. 134-140.

16. Ищенко Е.П. Понятие и структура информационного обеспечения следственной деятельности. Вісник Луганського державного університету внутрішніх справ імені. Е.О. Дідоренка. 2008. Спец. вип. № 5. Ч. 1. С. 3-12.

17. Колеснікова М.В. Поняття, сутність та значення інформаційного забезпечення правоохоронних органів України. Право і безпека. 2011. № 5 (42). С. 116-119.

\section{Анотація}

Калатур М. В. До проблеми визначення поняття інформаційного забезпечення діяльності слідчих органів в Україні. - Стаття.

Актуальність статті полягає в тому, що наукова організація праці й інформаційне забезпечення як одна з її складових частин у слідчих підрозділах правоохоронних органів України є пріоритетним напрямом реформування, адже широке застосування інформаційно-комунікаційних технологій та інструментів наукової організації праці є важливою передумовою підвищення ефективності діяльності слідчих органів. Метою статті є надання визначення поняття інформаційного забезпечення діяльності слідчих органів в Україні. У статті, на основі аналізу наукових поглядів учених та норм чинного законодавства щодо тлумачення понять «інформація» й «інформаційне забезпечення», запропоновано авторське визначення терміна «інформаційне забезпечення діяльності слідчих органів в Україні», яке варто розуміти як складову частину механізму організації слідчої діяльності, що в адміністративно-правовому плані передбачає одержання, збирання, реєстрацію, обробку, передачу, збереження та надання інформації шляхом створення інформаційних ресурсів, баз і систем, автоматизованих робочих місць із використанням новітніх методів і технологій. Наголошено, особливе значення інформаційне забезпечення має під час розслідування кримінальних справ в умовах дефіциту відомостей, коли слідчий відчуває брак даних, необхідних йому як для організації розслідування, так і для виявлення слідів злочину, з'ясування механізму злочинної діяльності, встановлення винних у вчиненні злочину тощо. З'ясовано, що змістом інформаційного забезпечення $€$ створення, функціонування та вдосконалення інформаційних систем, які являють собою апаратно-програмні комплекси засобів, що дозволяють здійснювати збір, обробку, накопичення криміналістично значущих даних, іх видачу на запити споживача. Визначено, що під інформаційним забезпеченням діяльності слідчих органів варто розуміти складову частину механізму організації слідчої діяльності, що в адміністративно-правовому плані передбачає одержання, збирання, реєстрацію, обробку, передачу, збереження та надання інформації шляхом створення інформаційних ресурсів, баз і систем, автоматизованих робочих місць із використанням новітніх методів і технологій.

Ключові слова: інформація, інформаційне забезпечення, діяльність, слідчі органи в Україні.

\section{Summary}

Kalatur M. V. On the problem of defining the concept of informational support of the activities of investigative bodies in Ukraine. - Article.

The relevance of the article is that the scientific organization of labor and information support, as one of its components, in the investigative units of law enforcement agencies of Ukraine is a priority area of reform, because the widespread use of information and communication technologies and tools of scientific organization of labor is an important prerequisite body. The purpose of the article is to provide a definition of the concept of information support for the activities of investigative bodies in Ukraine. The article, based on the analysis of scientific views of scientists and current legislation on the interpretation of the concepts of "information" and "information support", proposes the author's definition of "information support of investigative bodies in Ukraine", which should be understood as part of the mechanism in the administrative and legal plan provides for the receipt, collection, registration, processing, transmission, storage and provision of information by creating information resources, databases and systems, automated workplaces using the latest methods and technologies. It is emphasized that information support is especially important during the investigation of criminal cases in conditions of lack of information, when the investigator lacks the data he needs, both to organize the investigation 
and to identify traces of the crime, to clarify the mechanism of criminal activity, to establish perpetrators. etc. It was found that the content of information support is the creation, operation and improvement of information systems, which are hardware and software systems that allow the collection, processing, accumulation of forensic data, their issuance at the request of the consumer. It is determined that under the information support of the investigative bodies to understand a component of the mechanism of organization of investigative activities, which in administrative law provides for obtaining, collecting, registering, processing, transmitting, storing and providing information by creating information resources, databases and systems, automated workplaces. using the latest methods and technologies.

Key words: information, information support, activity, investigative bodies in Ukraine. 